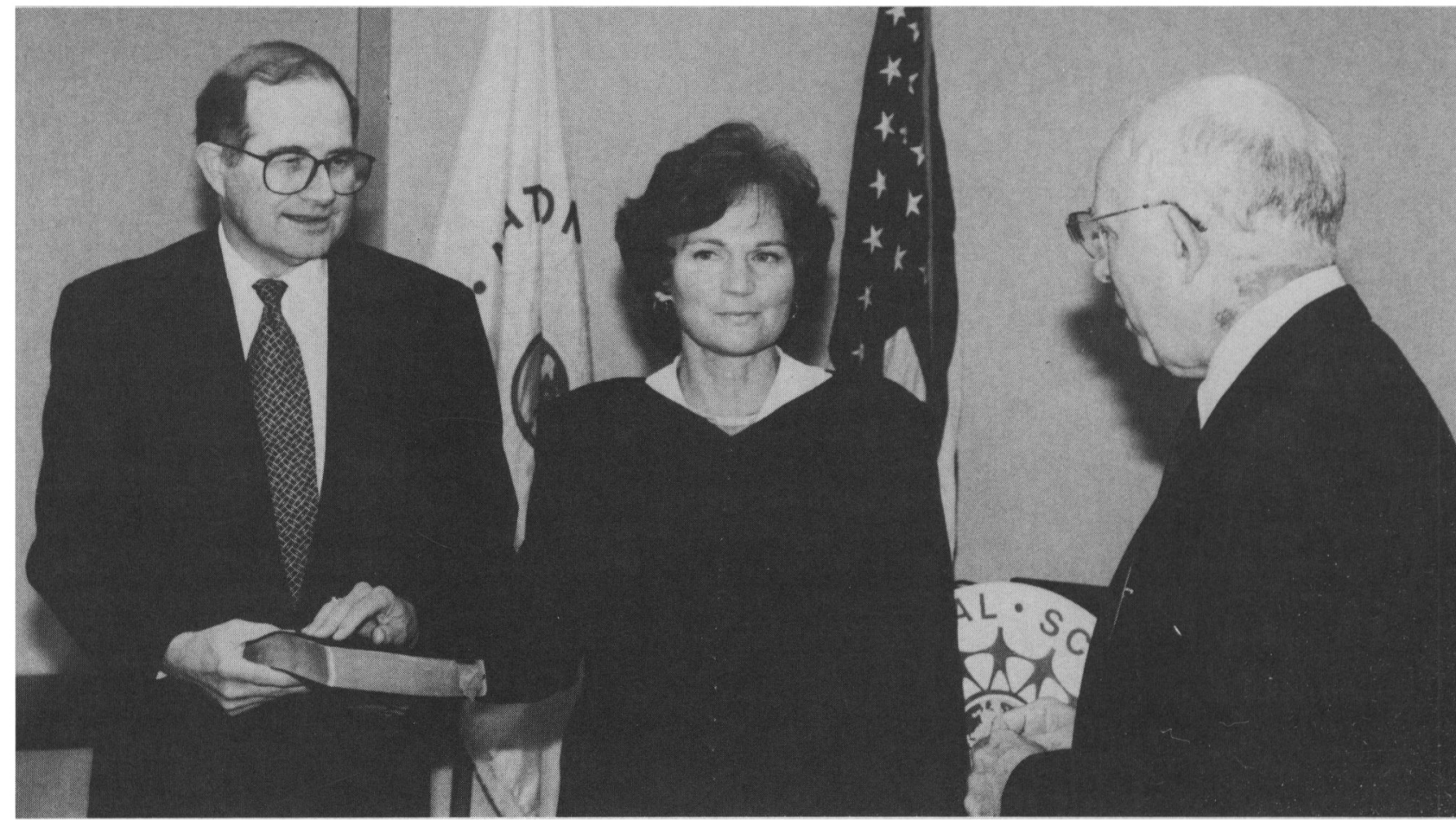

Anne Peterson being sworn in as new deputy director of the National Science Foundation by Presidential Science Advisor John Gibbons ( $\mathrm{r}$ ) and NSF Director Neal Lane (1).

Valery Zakharov, Nizhny

Novgorod Institute of Foreign

Languages

Sergei Zasorin, Moscow State Pedagogical University.

\section{Peterson Named Deputy Director, NSF}

Anne Peterson has assumed the position of deputy director of the National Science Foundation following a ceremony August 18, 1994. Peterson, who will also serve as chief operating officer, becomes the first woman in the agency's history to hold either of its top two posts. Formerly Vice President for Research and Dean of the Graduate School at the University of Minnesota, Peterson will now oversee the NSF's daily operations and implementation of government-wide system reforms. Peterson was nominated by President Clinton and following her confirmation by the Senate was administered the oath of office by Presidential Science Advisor John Gibbons.

\section{Write Congress on Behalf of the Social Sciences and the Humanities}

The American Political Science Association is a member of the Consortium of Social Science Associations, whose mission is to educate lawmakers about the nature and uses of social science. COSSA also lobbies funds for social science research shown primarily in the National Science Foundation budget. Likewise, the Association is a member of the National Humanities Alliance, whose purpose is to promote public awareness of lobby for research funds in the humanities as shown in the budget of the National Endowment for the Humanities. Members of Congress ask how NSF and NEH serve the country, their states and districts; some members also ask what purposes social science and the humanities, in general, and political science, in particular, serve.

Members of Congress should hear from their constituents that
National Science Foundation and National Endowment for the $\mathrm{Hu}$ manities funding has been used in their districts. APSA reminds members that it is important, both upon receipt of an NSF or NEH grant and upon completion of the grant, to write a letter to their senators and representatives. The letters will remind members of Congress that voters in their states and districts benefit from NSF and NEH funding. Such communications will also educate members of Congress as to the work of political scientists.

\section{Forty-Second Class of Congressional Fellows Begins 1994-95 Program}

Winners of the 1994-95 Congressional Fellowship Program competition for political scientists, journalists and federal employees were announced in the September 1994 issue of this publication.

In addition, medical professionals and international participants have 